\title{
Effects of dietary flavonoids on performance, blood constituents, carcass composition and small intestinal morphology of broilers: a meta-analysis
}

\author{
Tri Rachmanto Prihambodo ${ }^{1,2}$, Muhammad Miftakhus Sholikin ${ }^{1,2}$, Novia Qomariyah ${ }^{1,2,3}$, \\ Anuraga Jayanegara ${ }^{2,4}$, , Irmanida Batubara ${ }^{5}$, Desianto Budi Utomo ${ }^{6}$, and Nahrowi Nahrowi ${ }^{4}$
}

\author{
* Corresponding Author: Anuraga Jayanegara \\ Tel: +62-251-8626213, Fax: +62-251-8626213, \\ E-mail: anuraga.jayanegara@gmail.com \\ ${ }^{1}$ Graduate Study Program of Nutrition and \\ Feed Science, Faculty of Animal Science, IPB \\ University, Bogor 16680, Indonesia \\ ${ }^{2}$ Animal Feed and Nutrition Modelling \\ (AFENUE) Research Group, Faculty of \\ Animal Science, IPB University, Bogor 16680, \\ Indonesia \\ ${ }^{3}$ South Sulawesi Assessment Institute of \\ Agriculture Technology, Makassar 90242, \\ Indonesia \\ ${ }^{4}$ Department of Nutrition and Feed \\ Technology, Faculty of Animal Science, IPB \\ University, Bogor 16680, Indonesia \\ ${ }^{5}$ Department of Chemistry, Faculty of \\ Mathematics and Natural Sciences, IPB \\ University, Bogor 16680, Indonesia \\ ${ }^{6}$ PT. Charoen Pokphand, Jakarta 14430, \\ Indonesia \\ ORCID \\ Tri Rachmanto Prihambodo \\ https://orcid.org/0000-0002-7545-722X \\ Muhammad Miftakhus Sholikin \\ https://orcid.org/0000-0001-8677-6982 \\ Novia Qomariyah \\ https://orcid.org/0000-0002-6545-1326 \\ Anuraga Jayanegara \\ https://orcid.org/0000-0001-7529-9770 \\ Irmanida Batubara \\ https://orcid.org/0000-0001-8201-7807 \\ Desianto Budi Utomo \\ https://orcid.org/0000-0003-0895-8814 \\ Nahrowi Nahrowi
}

https://orcid.org/0000-0002-5384-9214

Submitted May 31, 2020; Revised Jun 26, 2020; Accepted Jul 28, 2020
Objective: This study aims to evaluate the influence of dietary flavonoids on the growth performance, blood and intestinal profiles, and carcass characteristics of broilers by employing a meta-analysis method.

Methods: A database was built from published studies which have reported on the addition of various levels of flavonoids from herbs into broiler diets and then monitored growth performance, blood constituents, carcass proportion and small intestinal morphology. A total of 42 articles were integrated into the database. Several forms of flavonoids in herbs were applied in the form of unextracted and crude extracts. The database compiled was statistically analyzed using mixed model methodology. Different studies were considered as random effects, and the doses of flavonoids were treated as fixed effects. The model statistics used were the p-values and the Akaike information criterion. The significance of an effect was stated when its $\mathrm{p}$-value was $<0.05$.

Results: Dietary flavonoids increased (quadratic pattern; $p<0.05$ ) the average daily gain of broilers in the finisher phase. There was a reduction $(\mathrm{p}<0.01)$ in the feed conversion ratio of the broilers both in the starter (linear pattern) and finisher phases (quadratic pattern). The mortality rate tended to decrease linearly $(\mathrm{p}<0.1)$ with the addition of flavonoids, while the carcass parameter was generally not influenced. A reduction $(\mathrm{p}<0.001)$ in cholesterol and malondialdehyde concentrations (both linearly) was observed, while super oxide dismutase activity increased linearly $(\mathrm{p}<0.001)$. Increasing the dose of flavonoids increased $(\mathrm{p}<0.01)$ the villus height $(\mathrm{VH})$ and villus height and crypt depth $(\mathrm{VH}: \mathrm{CD})$ ratio $(\mathrm{p}<0.05)$ in the duodenum. Similarly, the VH:CD ratio was elevated $(\mathrm{p}<0.001)$ in the jejunum following flavonoid supplementation.

Conclusion: Increasing levels of flavonoids in broilers diet leads to an improvement in growth performance, blood constituents, carcass composition and small intestinal morphology.

Keywords: Broiler; Flavonoid; Growth Performance; Carcass and Blood Composition; Small Intestinal Morphology; Meta-analysis

\section{INTRODUCTION}

Two main goals of the broiler industry are to improve growth performance and optimize the quality of broiler meat. In addition, another objective at present is to produce healthy broiler meat without the addition of any antibiotic growth promoters. This is considered to be important, as regulations in many countries prohibit the use of antibiotics and hormones for growth [1]. However, the lack of antibiotic use in broiler production, especially in tropical countries, may potentially interfere with performance and tend to increase death rates among broilers because of their diminished health status [2]. Broiler production in 
the tropics faces greater obstacles than in sub-tropical or temperate regions, such as lower growth performance, depressed immune systems, low carcass quality and high mortality rates due to the higher temperatures and humidity, which lead to an enhanced heat stress response [3-5]. Some of the alternatives to antibiotics to overcome such problems are plant secondary metabolites such as tannins, flavonoids, saponins and essential oils [6]. These natural plant compounds have been reported to be able to replace antibiotics without negatively interfering with the main production parameters of broiler [6-8].

One of the potential secondary metabolites for use in broiler production are flavonoids, a compound that can be found in various parts of plants, such as the fruits, leaves, stems, and bark. It had been reported that flavonoids can be used as human and animal medicine since the compound possesses antibacterial, antioxidant, antiinflammation and hepatoprotective properties $[9,10]$. Flavonoids have positive effects on the digestive tract and cardiovascular system, stimulate the release of insulin hormone [11], modulate lipid metabolism, and improve antioxidant activity in the carcass of broiler. However, they have also been reported to have some negative effects, such as the possibility of acting as mutagens, pro-oxidants that generate free radicals, and as inhibitors of key enzymes involved in hormone metabolism when fed in high dosages [12]. Despite a number of experiments regarding the influence of flavonoids on broilers, to date there has been no meta-analysis study which has attempted to quantitatively summarize such a relationship. Therefore, the aim of this paper was to evaluate the influence of dietary flavonoids on growth performance, blood and intestinal profiles, and carcass characteristics of broilers by employing a meta-analysis method.

\section{MATERIALS AND METHODS}

\section{Development of the database}

A database was built from published studies which have reported on the addition of various levels of flavonoids from herbs to broiler diets. Accordingly, different forms and levels of flavonoid supplementation, as well as various flavonoid sources, were specified in the database. Science Direct, Google Scholar and Scopus were used as the search tools to compile the related articles, using the keywords "flavonoid", "herbs", and "broiler". Growth performance (body weight, average daily gain $[A D G]$, daily feed intake, feed conversion ratio [FCR], and mortality); blood constituents (glucose, cholesterol, triglyceride, high-density lipoprotein [HDL], low-density lipoprotein [LDL], malondialdehyde [MDA], and superoxide dismutase); carcass proportion (weight, breast, leg, and abdominal fat); and small intestinal morphology (villus height $[\mathrm{VH}]$, crypt depth [CD], and ratio of villus height to crypt depth [VH:CD]) were the parameters included in the database.

The criteria for articles to be included in the database were that: i) they were published in English; ii) treatments included the addition of a flavonoid source to certain basal feeds; and iii) experiments were conducted in vivo on broilers. A total of 60 articles were initially found after searching using the above-mentioned keywords. All these papers were further evaluated on the basis of their abstracts and full texts, which resulted in 42 papers being integrated into the database (Table 1). When an article reported more than one experiment, each of these was encoded separately. As indicated in Table 1, several forms of flavonoids in herbs were applied as unextracted and crude extracts. The supplementary doses ranged from 0 (control) to $60,000 \mathrm{mg} / \mathrm{kg}$ of diet. Broiler types integrated in the present study were Ross 308 , Cobb 500 and Arbor Acres which are considered as fastgrowing broilers. In the process of tabulating the data into the database, data for similar parameters were converted into the same measurement units, which facilitated further data analysis.

\section{Analysis of data}

The database was statistically analyzed using mixed model methodology in which the model has been widely used in meta-analysis research related to animal nutrition $[13,14]$. Different studies were considered as random effects, and the doses of flavonoids were treated as fixed effects. The following statistical model was used:

$$
Y_{i j}=B_{0}+B_{1} X_{i j}+B_{2} X_{i j}^{2}+s_{i}+b_{i} X_{i j}+e_{i j}
$$

where $Y_{i j}=$ dependent variable, $B_{0}=$ overall intercept across all studies (fixed effect), $B_{1}=$ linear regression coefficient of $\mathrm{Y}$ on X (fixed effect), $B_{2}=$ quadratic regression coefficient of $\mathrm{Y}$ on X (fixed effect), $X_{i j}=$ value of the continuous predictor variable (flavonoid addition level), $s_{i}=$ random effect of study $i, b_{i}=$ random effect of study $i$ on the regression coefficient of $Y$ on $X$ in study $i, e_{i j}=$ the unexplained residual error. When the respective quadratic regression model was not significant at $\mathrm{p}<0.05$, the corresponding linear regression mixed model was applied. Variable study was declared in the class statement since it does not contain any quantitative information. The model statistics used were p-values and the Akaike information criterion. The significance of an effect was stated when the $\mathrm{p}$-value was $<0.05$. All statistical analyses were carried out using R software, version 3.60.

\section{RESULTS}

The addition of flavonoids quadratically increased $(\mathrm{p}<0.05)$ the ADG of broilers in the finisher phase, but the effect was 
Table 1. Studies included in the meta-analysis of flavonoid addition on performance, carcass, blood composition and small intestinal morphology of broilers

\begin{tabular}{|c|c|c|c|c|c|c|}
\hline No & Reference & Period (d) & Source & Form & Flavonoid type & Dose (mg/kg) \\
\hline 1 & Abolfathi et al [16] & $1-42$ & Inula helenium & Crude extract & Kaempferol, quercetin & $0-1,000$ \\
\hline 2 & Akbarian et al [17] & $22-38$ & Citrus aurantium & Crude extract & Quercetin, luteolin, rutin, and hesperitin & $0-400$ \\
\hline 3 & Daramola [18] & $28-56$ & Vernonia amygdalina, Moringa oleifera & Unextracted & Quercetin & $0-2,000$ \\
\hline 4 & Kishawy et al [25] & $1-42$ & Punica granatum & Crude extract & Myricetin, quercetin & $0-1,000$ \\
\hline 5 & Habibian et al [26] & $1-49$ & Portulaca oleacea & $\begin{array}{l}\text { Unextracted, } \\
\text { crude extract }\end{array}$ & Kaempferol, quercetin & $0-3,000$ \\
\hline 6 & Ahmadipour and Khajali [27] & $1-42$ & Urtica dioica & Unextracted & Quercetin, kaempferol, isorhamnetein & $0-15,000$ \\
\hline 7 & Abdel-Azeem and Basyony [35] & $1-42$ & Alpinia galangal & Crude extract & Kaempferol, kaempferide, galangin, alpinin & $0-750$ \\
\hline 8 & Aengwanich et al [36] & $28-35$ & Tamarindus indica & Crude extract & Quercetin & $0-500$ \\
\hline 9 & Arlette et al [37] & $1-21$ & Ageratum conyzoides & Crude extract & Kaempferol, quercetin and glycosides & $0-6,000$ \\
\hline 10 & Bai et al [38] & $1-41$ & Radix bupleuri, Radix astragali & Crude extract & $\begin{array}{l}\text { Quercetin, isorhamnetin, isorhamne- } \\
\text { tin-3-0-glucoside, puerarin, rutin, narcissin, } \\
\text { eugenin, saikochrome A, saikochromic } \\
\text { acid, 7,4'-dihydroxy-isoflavone-7-0- } \beta \text {-D-glu- } \\
\text { coside, saikochromoside A and saikoiso- } \\
\text { flavonoside }\end{array}$ & $0-800$ \\
\hline 11 & Brenes et al [39] & $1-42$ & Vitis vinifera & Crude extract & Catechin, epicatechin & $0-360$ \\
\hline 12 & Chamorro et al [40] & $1-21$ & Vitis vinifera & Crude extract & Catechin, epicatechin & $0-5,000$ \\
\hline 13 & Dilawar et al [41] & $1-35$ & Mentha arvensis, Geranium thunbergii & Crude extract & Quercetin & $0-1,000$ \\
\hline 14 & Dong et al [42] & $1-28$ & Camelia oleifera & Unextracted & Kaempferol & $0-500$ \\
\hline 15 & Duarte et al [43] & $1-42$ & Propolis & Crude extract & $\begin{array}{l}\text { Quercetin, rutin, caffeic acid, chrysin, } \\
\text { apigenin, and kaempferol }\end{array}$ & $0-500$ \\
\hline 16 & Goodarzi et al [44] & $1-42$ & Allium cepa & Unextracted & Quercetin and isorhamnetein & $0-30,000$ \\
\hline 17 & Abdel-Moneim et al [45] & $1-42$ & Punica granatum & Crude extract & Flavanols and anthocyanins & 0-10 \\
\hline 18 & Herrero-Encinas et al [46] & $22-42$ & Olea europaea & Crude extract & $\begin{array}{l}\text { Hesperidin, rutin, luteolin-7-0-glucoside, } \\
\text { apigenin, apigenin-7-0-glucoside, quercetin, } \\
\text { kaempferol }\end{array}$ & $0-750$ \\
\hline 19 & Jobe et al [47] & $1-96$ & Cassia abbreviate & Crude extract & & $0-500$ \\
\hline 20 & Jiang et al [48] & $1-42$ & Citri reticulatae pericarpium & Crude extract & Hesperidin & $0-48$ \\
\hline 21 & Khoobani et al [49] & $1-42$ & Chicorium intybus & Unextracted & Kaempferol & $0-2,000$ \\
\hline 22 & Nardoia et al [50] & $1-21$ & Vitis vinifera & Unextracted & Catechin and Epicatechin & $0-60,000$ \\
\hline 23 & Nkukwana et al [51] & $1-42$ & Moringa oleifera & Unextracted & $\begin{array}{l}\text { Kaempferol, quercetin, isorhamnetin, and } \\
\text { apigenin }\end{array}$ & $0-5,000$ \\
\hline 24 & Oso et al [52] & $1-42$ & Aerva lanata & Unextracted & Quercetin, kaempferol, and ferulic acid & $0-5,000$ \\
\hline 25 & Park et al [53] & $1-35$ & Saposhnikovia divaricata & Crude extract & Rutin and ferulate & $0-2,000$ \\
\hline 26 & Park et al [53] & $1-35$ & Scutellaria baicalensis & Crude extract & Quercetin and rutin & $0-500$ \\
\hline 27 & Park et al [54] & $1-35$ & $\begin{array}{l}\text { Saposhnikovia divaricate, Lonicera } \\
\text { japonica, Chelidonium majus }\end{array}$ & Crude extract & Quercetin and rutin & $0-1,000$ \\
\hline 28 & Pirgozliev et al [55] & $1-21$ & Carvacrol cinnamaldehyde & Unextracted & Quercetin & $0-100$ \\
\hline 29 & Placha et al [56] & $1-28$ & Thymus vulgaris & Crude extract & $\begin{array}{l}\text { Homoorientin, orientin, luteolin, kaempferol, } \\
\text { luteolin, pratansein }\end{array}$ & $0-1,000$ \\
\hline 30 & Rahimi et al [57] & $1-42$ & $\begin{array}{l}\text { Thymus vulgaris, Echinacea purpurea, } \\
\text { Allium sativum }\end{array}$ & Crude extract & $\begin{array}{l}\text { Quercetin, kaempferol, delphinidin, myrice- } \\
\text { tin, apigenin }\end{array}$ & $0-1,000$ \\
\hline 31 & Rashidi et al [58] & $1-42$ & Glycyrrhiza glabra & Crude extract & Kaempferol, quercetin & $0-500$ \\
\hline 32 & Rubio et al [59] & $1-21$ & Piper cubeba & Crude extract & $\begin{array}{l}\text { Rutin, quercetin, luteolin, hesperidin, biofla- } \\
\text { vonoids }\end{array}$ & $0-500$ \\
\hline 33 & Saeid et al [60] & $1-42$ & Zingiber officinale & Crude extract & $\begin{array}{l}\text { Quercetin, rutin, catechin, epicatechin, } \\
\text { kaempferol, and naringenin }\end{array}$ & $0-6,000$ \\
\hline 34 & Shen et al [61] & $1-42$ & Bambusoideae & Crude extract & Isoflavone, quercetin & $0-5,000$ \\
\hline 35 & Shirzadi et al [62] & $1-42$ & Prosopis farcta, Rhus coriaria & Crude extract & $\begin{array}{l}\text { Vicenin-2, Apigenin C-glycoside, } \\
\text { Iso-orientin (= Luteolin 6-C-glucoside), } \\
\text { Myricetin 3-O-glucoside, Vitexin, Luteolin } \\
\text { 7-0-glucoside, Isovitexin, Quercetin 3-0- } \\
\text { glucoside, Rutin, Quercetin 3-O-galactoside, } \\
\text { Chrysoeriol 7-0-glucoside, Kaempferol } \\
\text { 3-0-rutonoside, Isorhamnetin 3-O-rutinoside, } \\
\text { 5-deoxyluteolin, Caffeic acid derivative and } \\
\text { Luteolin }\end{array}$ & $0-200$ \\
\hline 36 & Teteh et al [63] & $1-28$ & Moringa oleifera & Crude extract & $\begin{array}{l}\text { Kaempferol, quercetin, isorhamnetin, and } \\
\text { apigenin }\end{array}$ & $0-20,000$ \\
\hline 37 & Vase-Khavari et al [64] & $1-42$ & Rhus coriaria, H. persicum, M. piperita & Unextracted & $\begin{array}{l}\text { Myricetin, quercetin, kaempferol, iso- } \\
\text { quercetin, rutin, afzelin, astragalin, } \\
\text { isorhamnetin }\end{array}$ & $0-5,000$ \\
\hline 38 & Viveros et al [65] & $1-21$ & Vitis vinifera & Crude extract & Catechin, epicatechin & $0-7,200$ \\
\hline 39 & Wang et al [66] & $1-42$ & Forsythia suspensa & Crude extract & Quercetin, rutin & $0-100$ \\
\hline 40 & Zhang et al [67] & $1-42$ & Ginkgo biloba & Crude extract & Quercetin, kaempferol, and isorhamnetin & $0-500$ \\
\hline 41 & Zhou et al [68] & $1-42$ & Scutellaria baicalensis & Crude extract & Trihydroxyflavone & $0-200$ \\
\hline
\end{tabular}


insignificant in the starter phase (Table 2). Feed intake was not affected at all by the addition of flavonoids. The addition reduced $(\mathrm{p}<0.01)$ the FCR of broilers both in the starter and finisher phases, in which the response was linear and quadratic, respectively. Based on the FCR parameter, the optimum flavonoid dosage for broilers was $0.83 \%$. The mortality rate tended to decrease linearly $(\mathrm{p}<0.1)$ with the addition of flavonoids. Carcass-related parameters were generally not influenced by flavonoids (Table 3), apart from the fact that broiler liver weight increased $(\mathrm{p}<0.05)$.

The effects of flavonoids on blood constituents and the small intestinal morphology of broilers are presented in Table 4 and 5, respectively. Cholesterol and MDA concentrations decreased linearly (both at $\mathrm{p}<0.001$ ), while super oxide dismutase activity increased $(p<0.001)$ linearly due to higher doses of dietary flavonoids. The addition decreased $(\mathrm{p}<0.05)$ triglyceride and low-density lipoprotein $(\mathrm{p}<0.001)$ concentrations in the blood of the broilers, following quadratic patterns. On the contrary, high-density lipoprotein concentration was elevated $(\mathrm{p}<0.01)$ quadratically following the flavonoid addition. With regard to small intestinal morphology, higher flavonoid doses increased $(\mathrm{p}<0.01) \mathrm{VH}$ and the VH:CD ratio $(p<0.05)$ in the duodenum. Similarly, the VH:CD ratio was elevated $(\mathrm{p}<0.001)$ in the jejunum and ileum $(\mathrm{p}<0.1)$ due to the flavonoid supplementation.

\section{DISCUSSION}

This meta-analysis study generally indicates the positive effects of dietary flavonoid addition on the growth performance,

Table 2. Regression equations on the influence of flavonoid-rich herb addition (in \% of diet as fed) on production performance of broilers

\begin{tabular}{|c|c|c|c|c|c|c|c|c|}
\hline \multirow{2}{*}{ Response parameter } & \multirow{2}{*}{ Model } & \multirow{2}{*}{$\mathbf{n}$} & \multicolumn{4}{|c|}{ Parameter estimates } & \multicolumn{2}{|c|}{ Model estimates } \\
\hline & & & Intercept & SE Intercept & Slope & SE Slope & p-value & $\mathrm{AIC}^{1)}$ \\
\hline \multicolumn{9}{|l|}{ Starter phase } \\
\hline ADG (g/bird/d) & $\mathrm{L}$ & 101 & 41.7 & 2.32 & 1.30 & 0.83 & 0.120 & 601 \\
\hline Feed intake (g/bird/d) & $\mathrm{L}$ & 105 & 63.4 & 3.51 & -0.52 & 0.60 & 0.387 & 625 \\
\hline FCR $(g / g)$ & $\mathrm{L}$ & 99 & 1.54 & 0.06 & -0.12 & 0.03 & $<0.001$ & -11.2 \\
\hline \multicolumn{9}{|l|}{ Finisher phase } \\
\hline \multirow[t]{2}{*}{ Bodyweight (g/bird) } & Q & 67 & 2,207 & 235 & 506 & 179 & 0.007 & 896 \\
\hline & & & & & $-1,808$ & 696 & 0.013 & 877 \\
\hline \multirow[t]{2}{*}{ ADG (g/bird/d) } & Q & 78 & 80.6 & 7.19 & 9.95 & 5.77 & 0.090 & 556 \\
\hline & & & & & -64.9 & 26.8 & 0.019 & 544 \\
\hline Bodyweight (g/bird) & $\mathrm{L}$ & 108 & 2,079 & 169 & 24.6 & 31.2 & 0.433 & 149 \\
\hline ADG (g/bird/d) & $\mathrm{L}$ & 104 & 58.0 & 4.26 & 1.26 & 1.08 & 0.245 & 701 \\
\hline Feed intake (g/bird/d) & $\mathrm{L}$ & 108 & 94.0 & 5.29 & -0.45 & 0.83 & 0.586 & 729 \\
\hline \multirow[t]{2}{*}{$\mathrm{FCR}(\mathrm{g} / \mathrm{g})$} & Q & 108 & 1.78 & 0.04 & -0.13 & 0.03 & $<0.001$ & -14.5 \\
\hline & & & & & 0.07 & 0.03 & $<0.001$ & 13.2 \\
\hline Mortality (\%) & $\mathrm{L}$ & 31 & 5.49 & 1.65 & -20.1 & 11.3 & 0.090 & 190 \\
\hline
\end{tabular}

SE, standard error, AIC, Akaike information criterion; Q, quadratic; L, linear; ADG, average daily gain; FCR, feed conversion ratio.

${ }^{1)} \mathrm{AIC}$ is an estimator of the relative quality of statistical models for a given set of data (smaller is better).

Table 3. Regression equation on the influence of flavonoid-rich herbs (in \% of diet as fed) on carcass composition of broiler

\begin{tabular}{|c|c|c|c|c|c|c|c|c|}
\hline \multirow{2}{*}{$\begin{array}{l}\text { Response parameter } \\
\text { (\% of total weight) }\end{array}$} & \multirow{2}{*}{ Model } & \multirow{2}{*}{$\mathbf{n}$} & \multicolumn{3}{|c|}{ Parameter estimates } & \multicolumn{3}{|c|}{ Model estimates } \\
\hline & & & Intercept & SE Intercept & Slope & SE Slope & p-value & $\mathrm{AIC}^{1)}$ \\
\hline Weight & $\mathrm{L}$ & 36 & 68.6 & 1.12 & -2.39 & 5.33 & 0.659 & 164 \\
\hline Liver & $\mathrm{L}$ & 49 & 2.42 & 0.09 & 0.36 & 0.14 & 0.018 & 43.0 \\
\hline Gizzard & $\mathrm{L}$ & 40 & 2.02 & 0.21 & 0.17 & 0.56 & 0.759 & 47.5 \\
\hline Abd fat & $\mathrm{L}$ & 55 & 1.65 & 0.10 & -0.93 & 0.67 & 0.171 & 20.7 \\
\hline
\end{tabular}

SE, standard error, AIC, Akaike information criterion; L, linear.

${ }^{1)} \mathrm{AIC}$ is an estimator of the relative quality of statistical models for a given set of data (smaller is better). 
Table 4. Regression equations on the influence of flavonoid-rich herbs (in \% of diet as fed) on blood constituents of broilers

\begin{tabular}{|c|c|c|c|c|c|c|c|c|}
\hline \multirow{2}{*}{ Response parameter } & \multirow{2}{*}{ Model } & \multirow{2}{*}{$\mathbf{n}$} & \multicolumn{4}{|c|}{ Parameter estimates } & \multicolumn{2}{|c|}{ Model estimates } \\
\hline & & & Intercept & SE Intercept & Slope & SE Slope & p-value & $\mathrm{AIC}^{1)}$ \\
\hline Glucose (mg/dL) & $\mathrm{L}$ & 12 & 206 & 9.81 & -28.8 & 17.9 & 0.151 & 93.6 \\
\hline Cholesterol (mg/dL) & $L$ & 26 & 111 & 13.0 & -165 & 46.6 & $<0.001$ & 225 \\
\hline \multirow{2}{*}{ Triglyceride (mg/dL) } & Q & 35 & 53.7 & 7.55 & -2.64 & 9.34 & 0.780 & 271 \\
\hline & & & & & -62.1 & 25.3 & 0.022 & 257 \\
\hline \multirow[t]{2}{*}{ High-density lipoprotein (mg/dL) } & Q & 30 & 59.0 & 7.51 & 17.0 & 13.9 & 0.235 & 220 \\
\hline & & & & & 79.0 & 22.6 & 0.006 & 204 \\
\hline \multirow[t]{2}{*}{ Low-density lipoprotein (mg/dL) } & Q & 30 & 60.3 & 13.1 & -179 & 37.8 & $<0.001$ & 275 \\
\hline & & & & & -292 & 46.0 & $<0.001$ & 255 \\
\hline $\mathrm{MDA}(\mathrm{nmol} / \mathrm{mL})$ & $\mathrm{L}$ & 23 & 4.67 & 0.65 & -8.20 & 0.99 & $<0.001$ & 66.6 \\
\hline Super oxide dismutase (U/mL) & L & 24 & 198 & 45.8 & 154 & 23.6 & $<0.001$ & 251 \\
\hline
\end{tabular}

SE, standard error; AIC, Akaike information criterion; L, linear; Q, quadratic; MDA, malondialdehyde.

1) $\mathrm{AIC}$ is an estimator of the relative quality of statistical models for a given set of data (smaller is better).

Table 5. Regression equations on the influence of flavonoid-rich herbs (in \% of diet as fed) on small intestinal morphology of broilers

\begin{tabular}{|c|c|c|c|c|c|c|c|c|}
\hline \multirow{2}{*}{ Response parameter } & \multirow{2}{*}{ Model } & \multirow{2}{*}{$\mathbf{n}$} & \multicolumn{4}{|c|}{ Parameter estimates } & \multicolumn{2}{|c|}{ Model estimates } \\
\hline & & & Intercept & SE Intercept & Slope & SE Slope & $\mathrm{p}$-value & $\mathrm{AIC}^{1)}$ \\
\hline \multicolumn{9}{|l|}{ Duodenum } \\
\hline Villus height ( $\mu \mathrm{m})$ & L & 29 & 1,488 & 93.4 & 1,773 & 554 & 0.005 & 347 \\
\hline Crypt depth ( $\mu \mathrm{m})$ & $L$ & 29 & 228 & 26.8 & 97.9 & 63.5 & 0.141 & 251 \\
\hline $\mathrm{VH}: \mathrm{CD}$ & $L$ & 29 & 7.01 & 0.80 & 10.6 & 4.90 & 0.045 & 92.1 \\
\hline \multicolumn{9}{|l|}{ Jejunum } \\
\hline Villus height ( $\mu \mathrm{m})$ & $\mathrm{L}$ & 35 & 1,197 & 116 & -12.3 & 8.56 & 0.166 & 428 \\
\hline Crypt depth ( $\mu \mathrm{m})$ & $\mathrm{L}$ & 35 & 164 & 20.1 & -2.78 & 1.15 & 0.025 & 299 \\
\hline $\mathrm{VH}: \mathrm{CD}$ & $L$ & 35 & 8.09 & 1.20 & 0.53 & 0.08 & $<0.001$ & 141 \\
\hline \multicolumn{9}{|l|}{ Ileum } \\
\hline Villus height ( $\mu m)$ & $\mathrm{L}$ & 13 & 677 & 65.0 & 211 & 578 & 0.725 & 141 \\
\hline Crypt depth ( $\mu \mathrm{m})$ & $\mathrm{L}$ & 14 & 137 & 7.60 & -194 & 36.7 & $<0.001$ & 93.6 \\
\hline $\mathrm{VH}: \mathrm{CD}$ & $\mathrm{L}$ & 14 & 5.12 & 0.79 & 8.70 & 4.61 & 0.096 & 42.3 \\
\hline
\end{tabular}

SE, standard error; AIC, Akaike information criterion; $\mathrm{VH}: \mathrm{CD}$, ratio of villus height and crypt depth; L, linear.

${ }^{1)} \mathrm{AIC}$ is an estimator of the relative quality of statistical models for a given set of data (smaller is better).

blood metabolites and small intestinal morphology of broilers. Flavonoids are a class of phytochemicals that possess antibacterial activity against a wide range of microbial species, including pathogenic and other undesirable bacteria present in the digestive tract. Pathogenic bacteria, as a main cause of disorders in the digestive tract, can apparently be inhibited by flavonoids. Such pathogens may injure the intestinal villi and therefore interfere with nutrient absorption [15]. Their population is reduced in the presence of flavonoids, leading to an improvement in the performance of broilers and a more efficient FCR. A lower pathogen community stimulates the growth and regeneration of intestinal villi and intensifies nutrient absorption. This is supported by the increase in the VH:CD ratio in the duodenum, jejunum, and ileum. The ratio itself is a histological index for intestinal digestive capacity; a higher value indicates that the chicken has better intestinal health and higher absorption capacity [16]. Therefore, promotion of performance results due to addition of flavonoids is inseparable from the high ratio of villi length and $\mathrm{CD}$. In addition, they may stimulate mucus secretion [17] resulting in better villus protection and an increase in the growth of probiotic bacteria in the intestine [18].

The meta-analysis shows limited effects of flavonoids on the carcass and organ composition of broilers, except for the liver. This was confirmed by previous studies $[19,20]$. The increase in liver weight due to the addition of flavonoids is apparently a result of the detoxification process in the liver [21]. This implies that flavonoids should be added at an appropriate dosage so that they do not have any detrimental effect on broiler metabolism and production. Nevertheless, the liver weight in this study ranged from $1.71 \%$ to $3.88 \%$ of the total carcass weight, which is still within the normal weight range; the normal liver weight in broilers is between $2.64 \%$ to $4.40 \%$ of total carcass weight [22]. The effects of flavonoids on blood metabolites are in line with various previous studies, for example cholesterol reduction [23,24]; HDL enhancement $[25,26]$; LDL reduction [25,26]; MDA reduction [27] 
and superoxide dismutase enhancement $[11,16]$. Flavonoids are known to have the ability to modulate fat metabolism, changing the profile of fatty acids and the omega 3 to omega 6 ratio, thereby reducing cholesterol and triglyceride levels [11]. Zhang et al [28] reported that flavonoids reduced the content of $\mathrm{CHO}$ compounds and total glucose which are the constituents of LDL, apparently due to the delay in the activity of Acyl-CoA cholesterol acyltransferase in liver hepatocellular carcinoma cells [29]. Flavonoids possess antioxidant activity which is also able to modify lipid metabolism by inhibiting LDL formation [26], in which it is regarded as a bad cholesterol that may induce coronary heart disease.

With regard to blood glucose levels, flavonoids contain $\beta$-flavonoid rings [30] which play a role in glucose inhibition by forming hydrogen bonds with the active site of enzymes involved in carbohydrate digestion and metabolism. It has been reported that flavonoids inhibit the activity of $\alpha$-glucosidase [31] and $\alpha$-amylase [32], resulting in a slowdown of glucose absorption. The compound inhibits a-glucosidase, which converts disaccharide to monosaccharide, and inhibits $\alpha$-amylase, which breaks down complex carbohydrates into monosaccharide. However, some studies have also reported that flavonoids had no effects on blood glucose level $[33,34]$. This meta-analysis indicates a non-significant effect of flavonoids on blood glucose, although the slope is clearly negative, most probably due to the low level of data available, thus leading to low statistical power.

\section{CONCLUSION}

The meta-analysis has discovered that increasing flavonoid levels in broiler diets leads to an improvement in growth performance, blood constituents, carcass composition and small intestinal morphology, based on various literatures. Interestingly, the $\mathrm{ADG}$ increase due to dietary flavonoids is linked with improvement in small intestinal morphology, such as VH and the VH:CD ratio, without interfering with carcass composition. The concentration of blood constituents such as cholesterol, MDA, triglycerides, and low-density lipoprotein falls with higher doses of flavonoids, while increasing super oxide dismutase activity and high-density lipoprotein.

\section{CONFLICT OF INTEREST}

We certify that there is no conflict of interest with any financial organization regarding the material discussed in the manuscript. PT. Charoen Pokphand is an employee of Utomo DB.

\section{ACKNOWLEDGMENTS}

This work is part of the research funded by the Indonesian
Ministry of Research and Technology /National Research and Innovation Agency through PMDSU grant, year 2020.

\section{REFERENCES}

1. Maron DF, Smith TJS, Nachman KE. Restrictions on antimicrobial use in food animal production: an international regulatory and economic survey. Glob Health 2013;9:48. https://doi.org/10.1186/1744-8603-9-48

2. Huyghebaert G, Ducatelle R, Immerseel FV. An update on alternatives to antimicrobial growth promoters for broilers. Vet J 2011;187:182-8. https://doi.org/10.1016/j.tvjl.2010.03. 003

3. Tirawattanawanich C, Chantakru S, Nimitsantiwong W, Tongyai S. The effects of tropical environmental conditions on the stress and immune responses of commercial broilers, Thai indigenous chickens, and crossbred chickens. J Appl Poult Res 2011;20:409-20. https://doi.org/10.3382/japr.201000190

4. Awad EA, Najaa M, Zulaikha ZA, Zulkifli I, Soleimani AF. Effects of heat stress on growth performance, selected physiological and immunological parameters, caecal microflora, and meat quality in two broiler strains. Asian-Australas J Anim Sci 2020;33:778-87. https://doi.org/10.5713/ajas.19. 0208

5. He J, Ma L, Qiu J, et al. Effects of compound organic acid calcium on growth performance, hepatic antioxidation and intestinal barrier of male broilers under heat stress. AsianAustralas J Anim Sci 2020;33:1156-66. https://doi.org/10. 5713/ajas.19.0274

6. Vidanarachchi JK, Mikkelsen LL, Constantinoiu CC, Choct M, Iji PA. Natural plant extracts and prebiotic compounds as alternatives to antibiotics in broiler chicken diets in a necrotic enteritis challenge model. Anim Prod Sci 2013;53: 1247-59. https://doi.org/10.1071/AN12374

7. Cho M, Smit MN, He L, Kopmels FC, Beltranena E. Effect of feeding zero- or high-tannin faba bean cultivars and dehulling on growth performance, carcass traits and yield of saleable cuts of broiler chickens. J Appl Poult Res 2019;28:1305-23. https://doi.org/10.3382/japr/pfz099

8. Tekce E, Çınar K, Bayraktar B, Takma C, Gül M. Effects of an essential oil mixture added to drinking water for temperature-stressed broilers: performance, meat quality, and thiobarbituric acid-reactive substances. J Appl Poult Res 2020;29: 77-84. https://doi.org/10.3382/japr/pfz030

9. Tim Cushnie TP, Lamb AJ. Antimicrobial activity of flavonoids. Int J Antimicrob Agents 2005;26:343-56. https://doi. org/10.1016/j.ijantimicag.2005.09.002

10. Chew YL, Chan EWL, Tan PL, Lim YY, Stanslas J, Goh JK. Assessment of phytochemical content, polyphenolic composition, antioxidant and antibacterial activities of Leguminosae medicinal plants in Peninsular Malaysia. BMC Complement 
Altern Med 2010;11:12. https://doi.org/10.1186/1472-688211-12

11. Kamboh AA, Zhu WY. Effect of increasing levels of bioflavonoids in broiler feed on plasma anti-oxidative potential, lipid metabolites, and fatty acid composition of meat. Poult Sci 2013;92:454-61. https://doi.org/10.3382/ps.2012-02584

12. Skibola CF, Smith MT. Potential health impacts of excessive flavonoid intake. Free Radic Biol Med 2000;29:375-83. https:// doi.org/10.1016/S0891-5849(00)00304-X

13. St-Pierre NR. Invited review: integrating quantitative findings from multiple studies using mixed model methodology. J Dairy Sci 2001;84:741-55. https://doi.org/10.3168/jds.S00220302(01)74530-4

14. Sauvant D, Schmidely P, Daudin JJ, St-Pierre NR. Metaanalyses of experimental data in animal nutrition. Animal 2008;2:1203-14. https://doi.org/10.1017/S175173110800 2280

15. Srividya AR, Dhanabal SP, Misra VK, Suja G. Antioxidant and antimicrobial activity of Alpinia officinarum. Indian J Pharm Sci 2010;72:145-8. https://doi.org/10.4103/0250-474X. 62233

16. Abolfathi ME, Tabeidian SA, Shahraki ADF, Tabatabaei SN, Habibian M. Comparative effects of $\mathrm{n}$-hexane and methanol extracts of elecampane (Inula helenium L.) rhizome on growth performance, carcass traits, feed digestibility, intestinal antioxidant status and ileal microbiota in broiler chickens. Arch Anim Nutr 2019;73:88-110. https://doi.org/10.1080/174503 9X.2019.1581027

17. Akbarian A, Golian A, Gilani A, et al. Effect of feeding citrus peel extracts on growth performance, serum components, and intestinal morphology of broilers exposed to high ambient temperature during the finisher phase. Livest Sci 2013;157: 490-7. https://doi.org/10.1016/j.livsci.2013.08.010

18. Daramola OT. Medicinal plants leaf meal supplementation in broiler chicken diet: effects on performance characteristics, serum metabolite and antioxidant status. Anim Res Int 2019; 16:3334-42.

19. Sadeghi G, Karimi A, Shafeie F, Vaziry A, Farhadi D. The effects of purslane (Portulaca oleracea L.) powder on growth performance, carcass characteristics, antioxidant status, and blood metabolites in broiler chickens. Livest Sci 2016;184:3540. https://doi.org/10.1016/j.livsci.2015.12.003

20. Pournazari M, AA-Qotbi A, Seidavi A, Corazzin M. Prebiotics, probiotics and thyme (Thymus vulgaris) for broilers: performance, carcass traits and blood variables. Rev Colomb Cienc Pecu 2017;30:3-10. https://doi.org/10.17533/udea.rccp.v30 n1a01

21. Salam S, Sunarti D, dan Isroli. The effect of black cumin (Nigella sativa) grinding supplementation on aspartate aminotransferase (AST), alanine aminotransferase (ALT) and liver weight on broiler. J Peternakan Indones 2014;16:40-5. https:// doi.org/10.25077/jpi.16.1.40-45.2014
22. Ologhobo AD, Apata DF, Oyejide A, Akinpelu O. Toxicity of raw limabeans (Phaseolus lunatus L.) and limabean fractions for growing chicks. Br Poult Sci 1993;34:505-22. https:// doi.org/10.1080/00071669308417606

23. Ouyang K, Xu M, Jiang Y, Wang W. Effects of alfalfa flavonoids on broiler performance, meat quality, and gene expression. Can J Anim Sci 2016;96:332-41. https://doi.org/10.1139/ cjas-2015-0132

24. Song D, Wang YW, Hou YJ, Dong ZL, Wang WW, Li AK. The effects of dietary supplementation of microencapsulated Enterococcus faecalis and the extract of Camellia oleifera seed on growth performance, immune functions, and serum biochemical parameters in broiler chickens. J Anim Sci 2016; 94:3271-7. https://doi.org/10.2527/jas.2016-0286

25. Kishawy ATY, Amer SA, Abd El-Hack ME, Saadeldin IM, Swelum AA. The impact of dietary linseed oil and pomegranate peel extract on broiler growth, carcass traits, serum lipid profile, and meat fatty acid, phenol, and flavonoid contents. Asian-Australas J Anim Sci 2019;32:1161-71. https:/doi.org/ 10.5713/ajas.18.0522

26. Habibian M, Sadeghi G, Karimi A. Comparative effects of powder, aqueous and methanolic extracts of purslane (Portulaca oleracea L.) on growth performance, antioxidant status, abdominal fat deposition and plasma lipids in broiler chickens. Anim Prod Sci 2019;59:89-100. https://doi.org/10.1071/AN 17352

27. Ahmadipour B, Khajali F. Expression of antioxidant genes in broiler chickens fed nettle (Urtica dioica) and its link with pulmonary hypertension. Anim Nutr 2019;5:264-9. https:// doi.org/10.1016/j.aninu.2019.04.004

28. Zhang BW, Li X, Sun WL, et al. Dietary flavonoids and acarbose synergistically inhibit $\alpha$-glucosidase and lower postprandial blood glucose. J Agric Food Chem 2017;65: 8319-30. https://doi.org/10.1021/acs.jafc.7b02531

29. Borradaile NM, Carroll KK, Kurowska EM. Regulation of HepG2 cell apolipoprotein B metabolism by the citrus flavanones hesperetin and naringenin. Lipids 1999;34:591-8. https:// doi.org/10.1007/s11745-999-0403-7

30. Xu H. Inhibition kinetics of flavonoids on yeast $\alpha$-glucosidase merged with docking simulations. Protein Pept Lett 2010;17: 1270-9. https://doi.org/10.2174/092986610792231492

31. Rosak C, Mertes G. Effects of acarbose on proinsulin and insulin secretion and their potential significance for the intermediary metabolism and cardiovascular system. Curr Diabetes Rev 2009;5:157-64. https://doi.org/10.2174/157339909788 920910

32. Tadera K, Minami Y, Takamatsu K, Matsuoka T. Inhibition of $\alpha$-glucosidase and $\alpha$-amylase by flavonoids. J Nutr Sci Vitaminol 2006;52:149-53. https://doi.org/10.3177/jnsv.52. 149

33. Biavatti MW, Bellaver MH, Volpato L, Costa C, Bellaver C. Preliminary studies of alternative feed additives for broilers: 
Alternanthera brasiliana extract, propolis extract and linseed oil. Braz J Poult Sci 2003;5:147-51. https://doi.org/10.1590/ S1516-635X2003000200009

34. Ammar NM, Al-Okbi SY. Effect of four flavonoids on blood glucose of rats. Arch Pharm Res 1988;11:166-8. https://doi. org/10.1007/BF02857723

35. Abdel-Azeem AS, Basyony M. Some blood biochemical, antioxidant biomarkers, lipid peroxidation, productive performance and carcass traits of broiler chicks supplemented with Alpinia galangal rhizomes extract during heat stress. Egypt Poult Sci J 2019;39:345-63. https://doi.org/10.21608/ epsj.2019.35009

36. Aengwanich W, Suttajit M, Narkkong NA. Effects of polyphenols extracted from tamarind (Tamarindus indica L.) seed coat on differential white blood cell count in broilers (Gallus domesticus) exposed to high environmental temperature. Int J Poult Sci 2009;8:957-62. https://doi.org/10.3923/ ijps.2009.957.962

37. Arlette NT, Nadia NAC, Jeanette Y, Gertrude MT, Josué WP, Mbida M. Anticoccidial effects of Ageratum conyzoides (Asteraceae) and Vernonia amygdalina (Asteraceae) leaves extracts on broiler chickens. South Asian J Parasitol 2019;2: 1-10. https://doi.org/10.9734/SAJP/2019/43746

38. Bai S, He C, Zhang K, et al. Effects of dietary inclusion of Radix bupleuri and Radix astragali extracts on the performance, intestinal inflammatory cytokines expression, and hepatic antioxidant capacity in broilers exposed to high temperature. Anim Feed Sci Technol 2020;259:114288. https://doi.org/10.1016/j.anifeedsci.2019.114288

39. Brenes A, Viveros A, Goñi I, Centeno C, Saura-Calixto F, Arija I. Effect of grape seed extract on growth performance, protein and polyphenol digestibilities, and antioxidant activity in chickens. Span J Agric Res 2010;8:326-33. https://doi.org/ 10.5424/sjar/2010082-1199

40. Chamorro S, Viveros A, Centeno C, Romero C, Arija I, Brenes A. Effects of dietary grape seed extract on growth performance, amino acid digestibility and plasma lipids and mineral content in broiler chicks. Animal 2013;7:555-61. https://doi.org/10. 1017/S1751731112001851

41. Dilawar MA, Saturno JFL, Mun HS, Kim DH, Jeong MG, Yang CJ. Influence of two plant extracts on broiler performance, oxidative stability of meat and odorous gas emissions from excreta. Ann Anim Sci 2019;19:1099-113. https://doi. org/10.2478/aoas-2019-0046

42. Dong ZL, Wang YW, Song D, et al. Effects of microencapsulated probiotics and plant extract on antioxidant ability, immune status and caecal microflora in Escherichia coli K88challenged broiler chickens. Food Agric Immunol 2019;30: 1123-34. https://doi.org/10.1080/09540105.2019.1664419

43. Duarte CRA, Eyng C, Murakami AE, Santos TC. Intestinal morphology and activity of digestive enzymes in broilers fed crude propolis. Can J Anim Sci 2014;94:105-14. https:// doi.org/10.4141/cjas2013-059

44. Goodarzi M, Landy N, Nanekarani S. Effect of onion (Allium cepa L.) as an antibiotic growth promoter substitution on performance, immune responses and serum biochemical parameters in broiler chicks. Health 2013;5:1210-5. https:// doi.org/10.4236/health.2013.58164

45. Abdel-Moneim MA, Hammady GA, Hassanin MS, ElChaghaby GA. The effect of using marjoram extract as natural growth promoter on the performance and intestinal bacteria of broiler chickens. J Anim Poult Prod 2015;6:64756. https://doi.org/10.21608/jappmu.2015.52946

46. Herrero-Encinas J, Blanch M, Pastor JJ, Mereu A, Ipharraguerre IR, Menoyo D. Effects of a bioactive olive pomace extract from Olea europaea on growth performance, gut function, and intestinal microbiota in broiler chickens. Poult Sci 2020; 99:2-10. https://doi.org/10.3382/ps/pez467

47. Jobe MC, Ncobela CN, Kunene NW, Opoku AR. Effects of Cassia abbreviata extract and stocking density on growth performance, oxidative stress and liver function of indigenous chickens. Trop Anim Health Prod 2019;51:2567-74. https:// doi.org/10.1007/s11250-019-01979-y

48. Jiang XR, Zhang HJ, Wang J, et al. Effect of dried tangerine peel extract supplementation on the growth performance and antioxidant status of broiler chicks. Ital J Anim Sci 2016; 15:642-8. https://doi.org/10.1080/1828051X.2016.1222246

49. Khoobani M, Hasheminezhad SH, Javandel F, et al. Effects of dietary chicory (Chicorium intybus L.) and probiotic blend as natural feed additives on performance traits, blood biochemistry, and gut microbiota of broiler chickens. Antibiotics 2020;9:5. https://doi.org/10.3390/antibiotics9010005

50. Nardoia M, Romero C, Brenes A, et al. Addition of fermented and unfermented grape skin in broilers' diets: effect on digestion, growth performance, intestinal microbiota and oxidative stability of meat. Animal 2020;14:1371-81. https:/doi.org/ 10.1017/S1751731119002933

51. Nkukwana TT, Muchenje V, Masika PJ, Hoffman LC, Dzama $\mathrm{K}$. The effect of Moringa oleifera leaf meal supplementation on tibia strength, morphology and inorganic content of broiler chickens. S Afr J Anim Sci 2014;44:228-39. https://doi.org/ 10.4314/sajas.v44i3.4

52. Oso AO, Suganthi RU, Reddy GBM, et al. Effect of dietary supplementation with phytogenic blend on growth performance, apparent ileal digestibility of nutrients, intestinal morphology, and cecal microflora of broiler chickens. Poult Sci 2019;98:4755-66. https://doi.org/10.3382/ps/pez191

53. Park JH, Pi SH, Kim IH. Growth performance, blood profile, nutrient digestibility and meat quality of broilers fed on diets supplemented with Scutellaria baicalensis extract. Eur Poult Sci 2016;80:1-10. https://doi.org/10.1399/eps.2016.155

54. Park JH, Kang SN, Chu GM, Jin SK. Growth performance, blood cell profiles, and meat quality properties of broilers fed with Saposhnikovia divaricata, Lonicera japonica, and 
Chelidonium majus extracts. Livest Sci 2014;165:87-94. https:// doi.org/10.1016/j.livsci.2014.04.014

55. Pirgozliev V, Mansbridge SC, Rose SP, Lillehoj HS, Bravo D. Immune modulation, growth performance, and nutrient retention in broiler chickens fed a blend of phytogenic feed additives. Poult Sci 2019;98:3443-9. https://doi.org/10.3382/ ps/pey472

56. Placha I, Takacova J, Ryzner M, et al. Effect of thyme essential oil and selenium on intestine integrity and antioxidant status of broilers. Br Poult Sci 2014;55:105-14. https://doi.org/10. 1080/00071668.2013.873772

57. Rahimi S, Teymouri Zadeh Z, Karimi Torshizi MA, Omidbaigi $\mathrm{R}$, Rokni H. Effect of the three herbal extracts on growth performance, immune system, blood factors and intestinal selected bacterial population in broiler chickens. J Agric Sci Technol 2011;13:527-39.

58. Rashidi N, Ghorbani MR, Tatar A, Salari S. Response of broiler chickens reared at high density to dietary supplementation with licorice extract and probiotic. J Anim Physiol Anim Nutr 2019;103:100-7. https://doi.org/10.1111/jpn.13007

59. Rubio MS, Laurentiz AC, Sobrane FoST, et al. Performance and serum biochemical profile of broiler chickens supplemented with Piper cubeba ethanolic extract. Braz J Poult Sci 2019;21:1-8. https://doi.org/10.1590/1806-9061-2018-0789

60. Saeid JM, Mohamed AB, AL-Baddy MA. Effect of aqueous extract of ginger (Zingiber officinale) on blood biochemistry parameters of broiler. Int J Poult Sci 2010;9:944-7. https:// doi.org/10.3923/ijps.2010.944.947

61. Shen MM, Zhang LL, Chen YN, et al. Effects of bamboo leaf extract on growth performance, meat quality, and meat oxidative stability in broiler chickens. Poult Sci 2019;98:678796. https://doi.org/10.3382/ps/pez404

62. Shirzadi H, Shariatmadari F, Torshizi MAK, et al. Plant extract supplementation as a strategy for substituting dietary antibiotics in broiler chickens exposed to low ambient temperature. Arch Anim Nutr 2020;74:206-21. https://doi.org/10.1080/ 1745039X.2019.1693860

63. Teteh A, Lawson E, Tona K, Decuypere E, Gbeassor M. Moringa oleifera leave: hydro-alcoholic extract and effects on growth performance of broilers. Int J Poult Sci 2013;12:401-5. https:// doi.org/10.3923/ijps.2013.401.405

64. Vase-Khavari K, Mortezavi SH, Rasouli B, Khusro A, Salem AZM, Seidavi A. The effect of three tropical medicinal plants and superzist probiotic on growth performance, carcass characteristics, blood constitutes, immune response, and gut microflora of broiler. Trop Anim Health Prod 2019;51: 33-42. https://doi.org/10.1007/s11250-018-1656-x

65. Viveros A, Chamorro S, Pizarro M, Arija I, Centeno C, Brenes A. Effects of dietary polyphenol-rich grape products on intestinal microflora and gut morphology in broiler chicks. Poult Sci 2011;90:566-78. https://doi.org/10.3382/ps.201000889

66. Wang L, Piao XL, Kim SW, Piao XS, Shen YB, Lee HS. Effects of Forsythia suspensa extract on growth performance, nutrient digestibility, and antioxidant activities in broiler chickens under high ambient temperature. Poult Sci 2008;87:128794. https://doi.org/10.3382/ps.2008-00023

67. Zhang X, Cao F, Sun Z, et al. Effect of feeding Aspergillus nigerfermented Ginkgo biloba-leaves on growth, small intestinal structure and function of broiler chicks. Livest Sci 2012;147: 170-80. https://doi.org/10.1016/j.livsci.2012.04.018

68. Zhou Y, Mao S, Zhou M. Effect of the flavonoid baicalein as a feed additive on the growth performance, immunity, and antioxidant capacity of broiler chickens. Poult Sci 2019;98: 2790-9. https://doi.org/10.3382/ps/pez071 